\title{
Calidad del plasma rico en plaquetas: estudio de la activación plaquetaria
}

\section{Platelet-rich plasma quality: a study on platelet activation}

\author{
C. Sáez-Torres Barrosoํ, J. Calvo Benitoํ, A. Gayà Puig²
}

Resumen: Objetivo. El plasma rico en plaquetas (PRP) es utilizado de forma cada vez más frecuente en técnicas quirúrgicas de regeneración tisular. No obstante, el procesamiento de la sangre hasta obtener PRP puede desencadenar la activación prematura de las plaquetas y la pérdida de los factores bioactivos. En este trabajo estudiamos la calidad de los concentrados de plaquetas obtenidos siguiendo la técnica de doble centrifugación en tubo. Método. Se someten $50 \mathrm{ml}$ de sangre a una primera centrifugación a $200 \mathrm{~g} 10$ minutos, se recoge el sobrenadante y se centrifuga a $700 \mathrm{~g} 15$ minutos. Posteriormente, tras eliminar las $2 / 3$ partes del plasma, se resuspenden las plaquetas y se analiza el grado de enriquecimiento, el estado de activación y la reserva funcional de las plaquetas. Resultados. El enriquecimiento en plaquetas del PRP fue de $364 \pm 177 \%(n=45)$ respecto de los niveles presentes en sangre total. Mediante el estudio de la expresión de CD62 por citometría de flujo se determinó el porcentaje de plaquetas activadas en las muestras de 8 donantes. Mientras que en la sangre no procesada se detectó un $2,7 \%$ de plaquetas activadas, tras la preparación del PRP éste era sólo de 3,6\%, aumentando hasta el 16\% en el concentrado almacenado toda la noche a $22^{\circ} \mathrm{C}$. Tras la estimulación con trombina el porcentaje de plaquetas activadas fue de 96,2\%. Conclusión. Este protocolo de preparación de PRP no produce una activación significativa de las plaquetas. La respuesta a la estimulación con trombina de los concentrados indica un buen estado de reserva plaquetaria.

Palabras clave: Regeneración ósea; Plasma rico en plaquetas; Activación plaquetaria; CD62.

Recibido: 11.03 .05

Aceptado: 28.05 .07
Abstract: Objective. Platelet Rich Plasma (PRP) is an autologous preparation currently used in oral and maxillofacial reconstructive surgery. Blood collection and preparation of platelet concentrates may lead to platelet activation and the premature loss of their granular load. In this study, we have analyzed the quality of the PRP obtained from a small volume of whole blood through a double centrifugation technique, so called "tube method". Design. We obtained $50 \mathrm{ml}$ of whole blood from 45 patients and centrifuged at $200 \mathrm{~g}$ for 10 minutes. The plasma and buffy-coat were collected and we then centrifuged at $700 \mathrm{~g}$ for 15 minutes. The pellet was resuspended after discarding 2/3 of the plasma. The platelet concentration, platelet activation and the functional response to thrombin were analyzed in these samples. Results. By using this method of PRP preparation, we obtained a $364 \pm 177 \%$ increase in platelet concentration in comparison with whole blood levels. Platelet activation, measured by flow cytometry analysis of CD62 expression, was of $2.7 \%$ in unprocessed blood and $3.6 \%$ in fresh PRP. This figure increased to $16 \%$ in PRP samples after overnight storage at room temperature. A percentage of $96 \%$ of platelets showed activation in PRP samples after thrombin stimulation. Conclusion. Our results show that platelets contained in PRP concentrates obtained by this method are not significantly activated. A good functional platelet reserve is preserved through the procedure, since platelets maintained a satisfactory response to thrombin after PRP preparation.

Key words: Bone regeneration; Platelet Rich Plasma; Platelet activation; CD62.

\footnotetext{
1 Médico.

2 Médico. Director del Banco de Tejidos de las Islas Baleares.

Fundació Banc de Sang i Teixits de les Illes Balears, España
}

\section{Correspondencia:}

Concepción Sáez-Torres Barroso.

Banc de Teixits. Fundació Banc de Sang i Teixits de les Illes Balears.

c/ Rosselló i Caçador 20. 07004 Palma de Mallorca. Baleares, España

Email: bteixits@bstib.com 


\section{Introducción}

La investigación en el campo de la regeneración ósea se orienta hacia la formación de un hueso de mayor calidad, de forma más temprana y, en ocasiones, en mayor cantidad. Los conocimientos sobre la fisiología de la reparación del hueso son utilizados a la hora de definir aquellas técnicas y materiales que puedan aportar las condiciones óptimas para este proceso. En este contexto se incluye el uso de diversas armas terapéuticas entre las que se encuentran los diferentes tipos de injertos y los factores de crecimiento contenidos en estos injertos, en los concentrados de plaquetas de uso local o en los preparados comerciales a partir de las formas recombinantes de los mismos. ${ }^{1-3}$

El plasma rico en plaquetas (PRP) consiste en un concentrado de plaquetas de origen autólogo que, en contacto con sustancias activadoras del proceso de coagulación, forma una red de fibrina de consistencia gelatinosa que contiene los diferentes elementos celulares (gel de plaquetas). El interés del empleo del gel de plaquetas es doble. Por un lado aporta una gran estabilidad en el relleno del defecto óseo, ya que se comporta como un excelente transportador de los injertos de hueso, en especial de aquellos injertos particulados y ofrece la posibilidad de generar una malla de fibrina que puede ser suturada y que colabora a mantener la estabilidad del injerto. Por otro lado, las células sanguíneas, en especial las plaquetas contenidas en el PRP, son una fuente de sustancias mediadoras capaces de acelerar o mejorar los procesos regenerativos. ${ }^{4,5}$ Entre estas sustancias destacan diversos factores de crecimiento tales como TGF- $\beta$, PDGF, VEGF, EGF e IGF. Varios estudios demuestran la actividad de estas sustancias en la estimulación de la angiogénesis, en la inducción de la quimiotaxis, proliferación y diferenciación de células progenitoras y en la síntesis de colágeno.6-8

Desde la descripción de las aplicaciones clínicas del PRP se han empleado varios protocolos de obtención del mismo en función de las necesidades de uso. En los trabajos iniciales de Marx, el PRP se obtenía mediante técnicas de aféresis. ${ }^{4}$ Esta forma de procesamiento, habitual para las plaquetas de uso transfusional, consigue concentrados de volumen importante pero está limitada por la necesidad de unas condiciones específicas por parte del centro extractor $\mathrm{y}$ del paciente. Al ampliarse las indicaciones de uso del PRP a técnicas de regeneración de defectos óseos de pequeño tamaño, habituales en el campo de la cirugía oral y maxilofacial, se simplificó la técnica de obtención, adaptándola a cantidades menores de sangre periférica extraída por venopunción en tubos de pequeño volumen. ${ }^{1,5,9-11}$ Esta sangre se somete a centrifugaciones sucesivas que permiten concentrar las plaquetas en la cantidad deseada. De esta manera se logra mayor facilidad y rapidez en la preparación del concentrado así como un menor coste y unas mínimas molestias para el paciente. Ambos procedimientos contemplan una serie de variables que pueden influir en la calidad y actividad biológica del producto final y que no se encuentran bien definidas en la actualidad. Entre estas variables destacan los diferentes pasos de centrifugación, que influyen tanto en la concentración como en el grado de activación de las plaquetas. Está demostrado que una activación prematura de las plaquetas conlleva una pérdida de factores que se eliminan o se degradan antes de alcanzar el lugar donde

\section{Introduction}

The investigation carried out in the field of bone regeneration is geared towards the formation of bone of greater quality at an earlier stage and, on occasions, of greater quantity. When defining the techniques and materials that can provide the best conditions for this process, a knowledge of the physiology behind bone repair is required. In this context a therapeutic arsenal is used that includes different types of grafts and the growth factors that are to be found in these grafts, which are used in platelet concentrations for local use, or as commercial preparations based on recombinant types. ${ }^{1-3}$

Platelet-rich plasma (PRP) consists in a platelet concentrate with an autologous origin that, when in contact with substances that activate the coagulation process, forms a fibrin mesh with a gelatinous consistency that contains different cellular elements (platelet gel). There is a two-fold interest in using platelet gel. On the one hand it provides great stability for filling a bone defect, as it acts as an excellent carrier of bone grafts, especially for bone chip grafts, and it offers the possibility of generating a fibrin mesh that can be sutured and that helps to maintain the stability of the graft. On the other hand, blood cells, especially PRP platelets, are a source of mediating substances that are able to accelerate or improve the regenerative processes. ${ }^{4,5}$ Among these substances, various growth factors stand out such as TCF- $\beta$, PDGF, VEGF, EGF and IGF. Various studies have shown the activity of these substances for stimulating angiogenesis, for the induction of chemotaxis, proliferation and differentiation of progenitor cells and in collagen synthesis. 6-8

Ever since the description of the clinical application of $P R P$, various protocols have been used for obtaining this, depending on what it was needed for. In the initial work by Marx, PRP was obtained by means of aphaeresis techniques. ${ }^{4}$ This type of processing, which was commonplace in transfusion platelets, achieves considerable concentration of volume, but it is limited because specific conditions are required of the extracting center and of the patient. As the indications for the use of PRP have been widened to regeneration techniques of small sized bone defects, which are habitual in the field of oral and maxillofacial surgery, the methods for obtaining this have become simplified, and they have been adapted to smaller quantities of peripheral blood extracted by venous puncture in small volume tubes. 1,5,9,10,11 This blood is subjected to successive centrifugation that permits concentrating the platelets to the desired amount. In this way the concentrate is prepared with greater ease and speed, and at a lesser cost, with a minimum discomfort for the patient. Both procedures take into account a series of variables that can influence the quality and biological activity of the final product, which are not currently well defined. Among these variables the different centrifugation steps stand out, as these influence the concentration as well as the degree of platelet activation. It has been demonstrated that pre- 
deben actuar.12,13 Por ello, para garantizar la obtención de unos resultados óptimos con el empleo del PRP, es necesario que los concentrados que se utilizan contengan un número adecuado de plaquetas y que estas plaquetas se hayan mantenido hasta su utilización en condiciones que garanticen la preservación de su capacidad funcional.

El objetivo de este estudio es determinar la calidad del plasma rico en plaquetas obtenido con el método de doble centrifugación en tubo. Con este fin analizamos el enriquecimiento celular en el producto final así como el estado de activación y la reserva funcional de las plaquetas contenidas en este PRP.

\section{Material y método}

\section{Obtención de las muestras}

Para la preparación de cada muestra de PRP del estudio se obtuvo sangre de una serie de donantes voluntarios sanos así como de pacientes a los que se iba a realizar un procedimiento quirúrgico de regeneración ósea. La cantidad de sangre total extraída de cada donante fue de $50 \mathrm{ml}$ en tubos de $5 \mathrm{ml}$ conteniendo citrato como anticoagulante (Venoject, TERUMO Europe, Leuven, Bélgica). Esta sangre fue procesada siguiendo el método de preparación de PRP en tubo. El procedimiento contempla una primera centrifugación lenta ( $200 \mathrm{~g}$ X $10 \mathrm{~min}$ ) tras la que se recoge el plasma sobrenadante junto con los primeros $\mathrm{mm}$ de la capa leucocitaria y de hematíes, seguido de una segunda centrifugación de mayor intensidad (700 g X $15 \mathrm{~min}$ ) que permite separar una fracción de plasma pobre en plaquetas (PPP) correspondiente a la porción superior, en volumen variable según la concentración celular que se desee obtener en el producto final, y la fracción restante de plasma rico en plaquetas (PRP).

La preparación de las muestras se realizó en campana de flujo laminar para evitar la contaminación de las mismas. El recuento celular de las muestras de sangre total y de PRP se llevó a cabo de forma automática (Ac-T5 diff AL,Beckman Coulter, CA).

\section{Técnica de citometría de flujo para \\ el análisis de la activación plaquetaria}

En las diferentes muestras del estudio se realizó un marcaje con anticuerpos específicos unidos a fluorocromos frente a las moléculas CD61 y CD62. El CD61 es una molécula que se expresa de forma normal en la superficie de las plaquetas y que permite definir la población plaquetaria. El análisis de CD62 (P selectina) constituye un marcador de activación de estos elementos celulares debido a que esta molécula, presente en los gránulos de las plaquetas, se expresa en la superficie de las mismas al ser activadas.

El doble marcaje se llevó a cabo añadiendo a las muestras concentraciones saturantes de anti-CD61 conjugado con fluoresceína (Caltag, Burlingame, CA) y anti-CD62 conjugado con ficoeritrina (Caltag, Burlingame, CA) e incubando durante 20 minutos a $22^{\circ} \mathrm{C}$ en la oscuridad. Tras la incubación se añadió $1 \mathrm{ml}$ de solución de paraformaldehído al $1 \%$ a cada tubo.

El control de activación se llevó a cabo estimulando una alícuota de PRP previamente diluida 1:10 en PBS, con trombina a mature platelet activation carries a loss factor, and the platelets are eliminated or degraded before reaching the area that they should act upon. 12,13 Therefore, in order to guarantee optimal results when using PRP, it is necessary for the concentrates used to contain a suitable number of platelets and for these platelets to have been maintained until used in conditions that guarantee the preservation of their functional capacity.

The object of this study was to determine the quality of platelet-rich plasma obtained with the double centrifugation tube method. With this aim, we analyze cell concentration in the final product as well as in the activated state, and the functional reserve of the platelets contained in this PRP.

\section{Material and method}

\section{Obtaining samples}

For preparing each sample of PRP in the study, blood was obtained from a series of healthy voluntary donors as well as from the patients who were to undergo a surgical bone regeneration procedure. The total amount of blood extracted from each donor was $50 \mathrm{ml}$ in $5 \mathrm{ml}$ tubes that contained citrate as an anticoagulant (Venoject, TERUMO Europe, Leuven, Belgium). This blood was processed following the tube preparation method for PRP. The procedure contemplates first a slow centrifugation ( $200 \mathrm{~g} \times 10 \mathrm{mins})$ after which the supernatant plasma is removed together with the first $\mathrm{mm}$ layer of red and white blood cells, followed by a second centrifugation of greater intensity ( $700 \mathrm{~g} X 15 \mathrm{mins}$ ) that permits separating a fraction of platelet-poor plasma (PPP) that corresponds to the upper portion, with a variable volume depending on the cell concentration in the final product that is desired, and the remaining fraction of plateletrich plasma (PRP).

The preparation of the samples was carried out in a laminar flow cabinet in order to avoid contamination. The cell count of the total blood sample and of the PRP was carried out automatically (Ac-T5 diff AL,Beckman Coulter, CA).

Flow cytometry technique for the analysis of platelet activation

Staining with specific antibodies was carried out of the different study samples together with fluorochromes versus CD61 and CD62 molecules. CD61 is a molecule that is expressed normally on the surface of platelets and it allows specifying the platelet population. CD62 analysis (P-selectin) is an activation marker of these cell elements because this molecule, which is present in the - granules of the platelets, is expressed on their surfaces on being activated.

Double staining was carried out and saturating concentrations of anti-CD61 conjugated with phycoerythrin (Caltag, Burlingame, $C A$ ) were added to the samples together with anti-CD62 conjugated with phycoerythrin (Caltag, Burlingame, 
una concentración de $1 \mathrm{U} / \mathrm{ml}$ final (Sigma Chemicals, St.Louis, MO), en presencia de $2 \mathrm{mM}$ Gly-Pro-Arg-Pro (GPRP, Sigma Chemicals, St.Louis, MO). Este péptido es un inhibidor de la polimerización de fibrina y de la agregación plaquetaria que impide que se forme el coágulo al activarse las plaquetas. Tras la adición del activador las muestras se incubaron a $37^{\circ} \mathrm{C}$ durante 15 minutos y se continuó con el protocolo de tinción descrito.

Las muestras fueron finalmente analizadas en un citómetro de flujo FACScan (Becton Dickinson, San José, CA) utilizando el programa Cell Quest (Becton Dickinson, San José, CA).

El grado de activación de las plaquetas se analizó a diferentes tiempos: sangre total antes de ser procesada, PRP recién preparado, PRP almacenado 24 horas a $22^{\circ} \mathrm{C}$ y PRP estimulado con trombina.

\section{Resultados}

\section{Preparación del PRP y recuento de plaquetas}

El PRP preparado en el laboratorio es dispensado al clínico de forma ambulatoria en viales estériles conteniendo las diferentes fracciones obtenidas a partir de la sangre del paciente. En un vial se dispensa el plasma rico en plaquetas, en otro la fracción correspondiente al plasma pobre en plaquetas y en un tercero la solución activadora que consiste en suero del propio paciente enriquecido con cloruro cálcico a una concentración final del 2,3\% (Fig. 1). Para obtener el gel de plaquetas tan sólo es necesario recuperar el PRP y la solución activadora mediante jeringas graduadas y mezclarlos en una proporción de 10:1 (0,1 ml de solución activadora por cada $\mathrm{ml}$ de PRP).

A lo largo del período de este estudio se recogieron muestras procedentes de 45 pacientes y se realizó un recuento celular en la sangre total y en una alícuota de PRP. El análisis de estas muestras reveló un enriquecimiento en plaquetas de $364 \pm 177 \%$ en el PRP respecto a los valores en sangre total.

\section{Análisis del grado de activación de las plaquetas}

Tal como se ha comentado anteriormente, la activación de las plaquetas durante el proceso de obtención del PRP, conlleva una liberación de los factores de crecimiento hacia el sobrenadante y su consiguiente pérdida de forma precoz. Por ello consideramos importante estudiar este factor como parámetro de influencia en la calidad del PRP.

El grado de activación de las plaquetas fue analizado en las muestras de PRP de 8 donantes a diferentes tiempos: sangre total, PRP recién obtenido y PRP tras 24 horas de almacenamiento a $22^{\circ} \mathrm{C}$. Para el estudio del estado de reserva funcional de las plaquetas se indujo la activación con trombina de los concentrados.
CA), which was incubated in the dark for 20 minutes at $22^{\circ} \mathrm{C}$. After incubation, $1 \mathrm{ml}$ of paraformaldehyde $1 \%$ solution was added to each tube.

The activation control was carried out by stimulating an aliquot of PRP that had previously been diluted at 1:10 in PBS with thrombin at a concentration of $1 \mathrm{U} / \mathrm{ml}$ final (Sigma Chemicals, St.Louis, $\mathrm{MO})$, in the presence of 2 mM Gly-Pro-Arg-Pro (GPRP, Sigma Chemicals, St. Louis, MO). This peptide is an inhibitor of fibrin polymerization and of platelet aggregates that stops clot formation as the platelets are activated. After adding the activator to the samples, these were incubated at $37^{\circ} \mathrm{C}$ for 15 minutes and the staining protocol mentioned was continued. The samples were finally analyzed in a FACScan flow cytometer (Becton Dickinson, San José, CA) using the Cell Quest program (Becton Dickinson, San José, $(A)$. The degree of platelet activation was analyzed at different times: total blood before processing, just separated PRP, PRP kept for 24 hours at $22^{\circ} \mathrm{C}$, and PRP stimulated with thrombin.

\section{Results}

PRP repair and platelet count

The laboratory-prepared PRP is dispensed to the clinician on an outpatient basis in sterile vials that contain the different fractions obtained from the patient's blood. One vial contains platelet-rich plasma, another contains the fraction corresponding to the platelet-poor plasma, and a third contains the activating solution that consists in the patient's very own serum enriched with calcium chloride with a final concentration of $2.3 \%$ (Fig. 1). For obtaining the platelet gel, only the PRP and the activating solution have to be recovered. This is done using graduated syringes and they are mixed at a 10:1 proportion ( $0.1 \mathrm{ml}$ of activating solution to every $\mathrm{ml}$ of PRP).

Throughout the duration of this study, samples from 45 patients were collected and a cell count was made of the whole blood and of the PRP aliquot. The analysis of these samples revealed a platelet concentration of $364 \pm 177 \%$ in PRP with regard to the whole blood values.

\section{Analysis of the degree of platelet activation}

As has been discussed previously, platelet activation dur- 
A

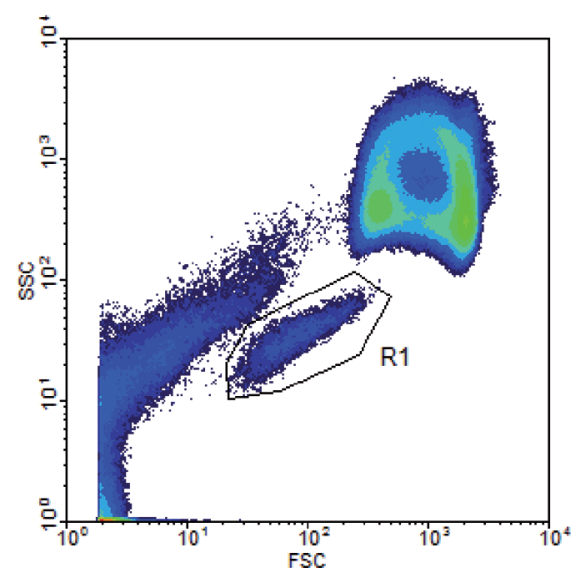

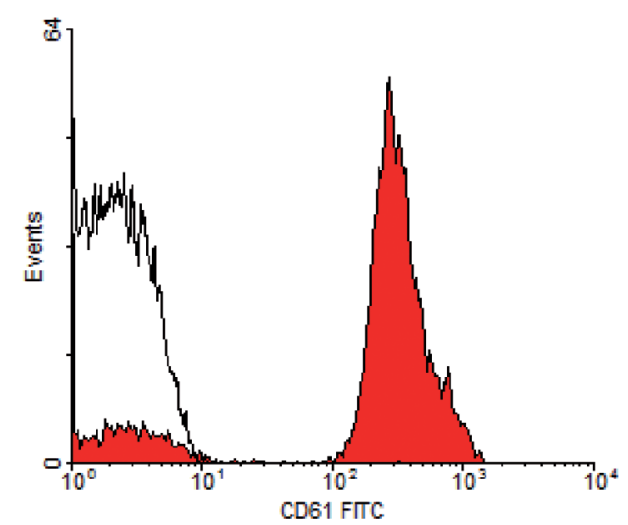

Figura 2. Análisis de las muestras por citometría de flujo. A) Imagen representativa de los elementos celulares en sangre total en función de sus características de tamaño (FSC) y rugosidad (SSC). La región marcada (R1) corresponde a la población de plaquetas. B) Intensidad de expresión del marcador CD61 de las células seleccionadas en R1. El histograma muestra una amplia positividad de estas células para el marcador de plaquetas.

Figure 2. Analysis of samples by cytometry flow. A) Image representative of the cellular elements in whole blood according to size characteristics (FSC) and roughness (SSC). The region marked (R1) corresponds to the platelet population. B) Intensity of CD61 expression marker in the selected cells in R1. The histogram shows ample positivity in these cells for the platelet marker.

La lectura de las muestras en el citómetro de flujo se llevó a cabo con una señal de amplificación logarítmica en los cuatro parámetros (tamaño, rugosidad, FL1, FL2) que controlan la adquisición. Para el análisis posterior se delimitó la región correspondiente a la población de plaquetas en función de sus características de tamaño y rugosidad (Fig. 2A). La expresión del marcador CD61 en más del $95 \%$ de las células seleccionadas confirma que la población incluida está compuesta esencialmente por plaquetas (Fig. 2B).

Una vez identificada la población de plaquetas se analizó en ella la expresión de CD62. El patrón de fluorescencia observado nos permite identificar el porcentaje de plaquetas que muestran una intensidad de expresión del marcador Fl2 por encima del nivel del control de la técnica y que traduce el estado de activación. La figura 3 muestra los diferentes patrones de fluorescencia que se observan según las plaquetas estén en reposo o activadas. En el PRP recién preparado (Fig. 3A) y a las 24 horas (Fig. 3B) el número de plaquetas activadas es escaso. Esta situación contrasta con el aumento significativo en la intensidad de la señal FL2 en las muestras estimuladas con trombina (Fig. 3C).

El análisis conjunto de todas las muestras generadas a partir de un mismo donante se representa en la figura 4 . En el histograma se aprecia como las curvas correspondientes a la activación de las plaquetas en sangre periférica, PRP fresco y PRP de 24 horas son prácticamente superponibles. Asimismo, el gráfico refleja el aumento significativo de la expresión del marcador de activación de las plaquetas en respuesta a la estimulación con trombina.

La media de los porcentajes de plaquetas activadas presentes en cada muestra, calculadas a partir del análisis de 8 donantes se representa en la figura 5. El porcentaje de plaquetas con expresión de CD62 en sangre periférica antes de ser procesada fue de 2,7 \pm $3,0 \%$. Después de los procesos de centrifugación, en el PRP fresco, esta media fue de $3,6 \pm 2,7 \%$. En este punto, la activación del concentrado tras la adición de trombina muestra un incremento de la ing the process for obtaining PRP, results in the release of growth factors towards the supernatant and as a result its early loss. Therefore, we consider studying this factor important as an influential parameter on the quality of PRP.

The degree of platelet activation was analyzed in the PRP samples of 8 donors at different times: whole blood, recently obtained PRP and PRP kept for 24 hours at $22^{\circ} \mathrm{C}$. For studying the state of the functional reserve of the platelets, activation was induced with thrombin of the concentrates.

The samples were read on the flow cytometer using a logarithm amplification signal of the four parameters (size, roughness, FL1, FL2) that control the acquisition. The region corresponding to the platelet population was delimited for later analysis, according to the size and roughness characteristics (Fig. 2A). The expression of the CD61 marker in more than $95 \%$ of the cells selected confirmed that the population included was composed essentially by platelets (Fig. 2B).

Once the platelet population had been analyzed, CD62 expression was then analyzed. The fluorescence pattern observed allows us to identify the percentage of platelets that show an intensity of the F12 expression marker above the control level of the technique, and that results in the activation state. Figure 3 shows the different fluorescence patterns that are observed depending on if the platelets are resting or active. In recently prepared PRP (Fig. $3 A$ ) and at 24 hours (Fig. 3B), the number of activated platelets is scarce. This situation is in contrast with the significant increase in the intensity of the FL2 signal in the samples stimulated with thrombin (Fig. 3C).

The analysis as a whole of all the samples generated from the same donor is represented in figure 4. The histogram shows the curves corresponding to the activation of platelets in peripheral blood, fresh PRP and PRP at 24 hours that 

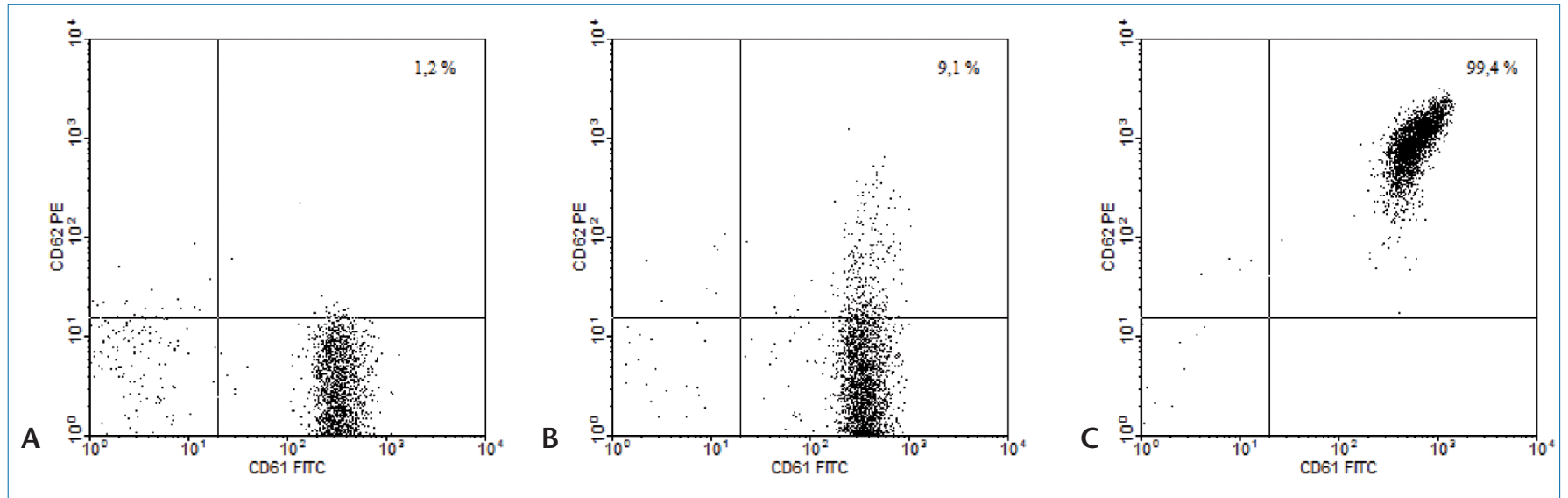

Figura 3. Análisis de la expresión de CD 61 (FL1) y CD62 (FL2) en la población de plaquetas de una muestra de PRP del estudio: (A) inmediatamente después de su preparación, (B) del mismo producto a las 24 horas y (C) tras la activación con trombina.

Figure 3. Analysis of CD61 (FL1) and CD62 (FL2) expression in a PRP sample of the study: (A) immediately after preparation, (B) the same product 24 hours later, and (C) after activation with thrombin.

expresión del CD 62 que alcanza el 96,2 $\pm 1,8 \%$ de las plaquetas. El análisis del PRP a las 24 horas de incubación a temperatura ambiente indica la presencia de un porcentaje de plaquetas activadas de $16,1 \pm 9,8 \%$. Al igual que en el PRP recién preparado, la adición de trombina conlleva un incremento del total de plaquetas activadas con cifras de $96,2 \pm$ $0,7 \%$.

\section{Discusión}

Todo proceso de manipulación de la sangre conlleva un cierto cambio en la ultraestructura de las células sanguíneas que puede traducirse en lesiones que afecten a su funcionalidad. Aunque estas lesiones son en gran parte reversibles, los cambios que tienen lugar en las plaquetas durante su procesamiento y almacenamiento actúan como parámetros útiles de predicción de la efectividad clínica de los concentrados. ${ }^{14}$

El análisis del PRP preparado según el protocolo de centrifugaciones sucesivas en tubo da como resultado un enriquecimiento de los concentrados entre 3 y 4 veces el recuento de plaquetas presente en la sangre periférica. Esta cantidad de plaquetas es suficiente para conseguir los objetivos que persigue la aplicación local de este preparado, diferentes de los del uso transfusional de las plaquetas. El PRP así obtenido permite la formación de un coágulo cuya consistencia es excelente para transportar diferentes tipos de injertos óseos y biomateriales. Asimismo, supone un aporte suplementario en el foco de lesión de una serie de factores de crecimiento que actúan como mediadores en los procesos de regeneración.

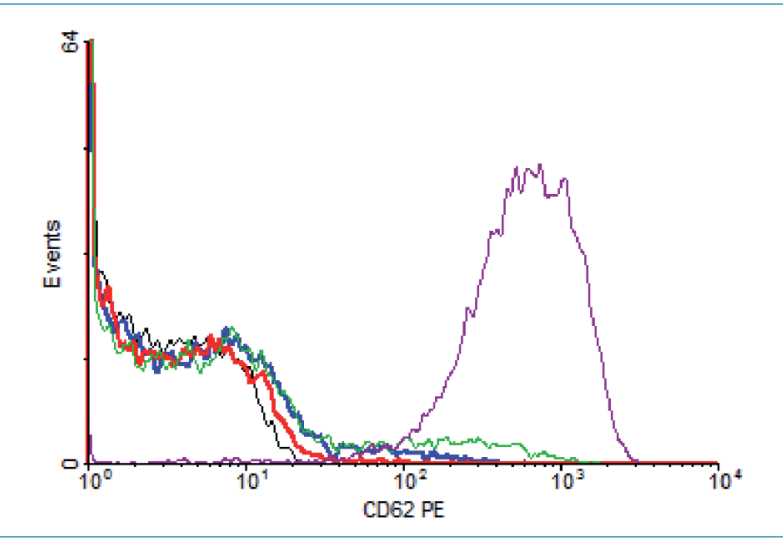

Figura 4. Expresión de CD62 en superficie plaquetaria. Las plaquetas se marcaron con el anticuerpo CD62-FITC y se analizaron por citometría de flujo según protocolo descrito en material y (negro), sangre total (rojo), PRP fresco (azul), PRP 24h

Figure 4. CD62 expression on platelet surface. The platelets were marwith the CD62-FITC antibody and they were analyzed by flow cytometry according to the protocol described in Material and Met hods. The different curves correspond to: negative FL2 control (black), whole blood (red), fresh PRP (blue), PRP 24h (green), activated PRP with thrombin (lilac). are practically superimposed. The graft also reflects the significant increase in the expression of the platelet activation marker in response to thrombin stimulation.

The mean percentage of activated platelets present in each sample, calculated from the analysis of 8 donors is represented in figure 5. The percentage in platelets with CD62 expression in peripheral blood before being processed was $2,7 \pm 3,0 \%$. After the centrifugation processes, in the fresh PRP, the mean was 3,6 $\pm 2,7 \%$. At this point, the activation of the concentrate after the addition of thrombin showed an increase in CD62 expression that reached $96,2 \pm 1,8 \%$ of the platelets. PRP analysis at 24 hours of incubation at room temperature showed a percentage of activated platelets of $16,1 \pm 9,8 \%$. As occurred with fresh PRP, the addition of thrombin carried a total increase of activated platelets of $96,2 \pm 0,7 \%$.

\section{Discussion}

All blood manipulation processes entail certain changes in the ultrastructure of blood cells that can result in lesions that affect how they function. Although these lesions are 
Si bien algunos autores defienden la idea de que la actividad biológica del PRP derivada del aporte de factores de crecimiento precisa de una cantidad entre $0,9-1 \times 106$ plaquetas/ $\mu$ l en el volumen habitual de concentrado $(6-10 \mathrm{ml}),{ }^{1}$ no parece existir ningún estudio concluyente que lo demuestre. No está definido el número de plaquetas necesario para obtener una cantidad adecuada de cada uno de los factores producidos por las mismas, del mismo modo que no está comprobado que el número de células contenidas en el concentrado sea el único determinante de la cantidad de factores liberados. Weibrich y Kleis han comparado en sus trabajos dos sistemas de preparación de PRP, a través de un análisis del rendimiento de plaquetas obtenido con cada sistema y la cuantificación de los principales factores de crecimiento contenidos en el producto final. ${ }^{15}$ Estos autores concluyen que, si bien existe una asociación significativa entre el número de plaquetas y la concentración de TGF-

$\beta$, esta asociación no es significativa para los otros factores analizados (PDGF, IGF), por lo que el número de plaquetas por si sólo no puede utilizarse para predecir la cantidad de factores de crecimiento que serán producidos. El trabajo de Zimmerman y cols. ${ }^{13}$ también presenta resultados similares en el análisis de los factores presentes en concentrados de plaquetas obtenidos por diferentes técnicas. Los autores señalan las diferencias en el estado de activación de las plaquetas como uno de los factores que contribuyen a esta variabilidad. Por otro lado, Dugrillon y cols. ${ }^{12}$ estudiaron el recuento de plaquetas y el contenido en TGF- $\beta 1$ del PRP sometido en su procesamiento a diferentes fuerzas de centrifugación. Este trabajo muestra claramente que intensidades superiores a $800 \mathrm{~g}$ producen mayores rendimientos de plaquetas pero disminuyen la cantidad de TGF$\beta$ contenida en el producto final. Este descenso en la cantidad de factores es consecuencia de la activación de las plaquetas al ser sometidas a importantes fuerzas mecánicas, con consiguiente liberación al medio del contenido de los gránulos, que se pierde prematuramente al retirar la fracción sobrante de plasma. Por consiguiente, la efectividad del PRP no sólo tiene relación con el hecho de contener una determinada concentración de plaquetas, sino que es de gran importancia garantizar que éstas permanezcan intactas hasta su utilización.

En nuestro estudio, el grado de integridad las plaquetas en el PRP es analizado a través del estudio del estado de activación y de la reserva funcional de las mismas. La medida de expresión de CD62 y la respuesta a la estimulación con trombina son parámetros utilizados frecuentemente para el análisis de concentrados de plaquetas no sólo de aplicación local sino también para los de uso transfusional. ${ }^{14,16-18} \mathrm{La}$ cifra de 2,7\% de activación plaquetaria en sangre extraída por venopunción coincide con la publicada previamente. ${ }^{19}$
Expresion CD62

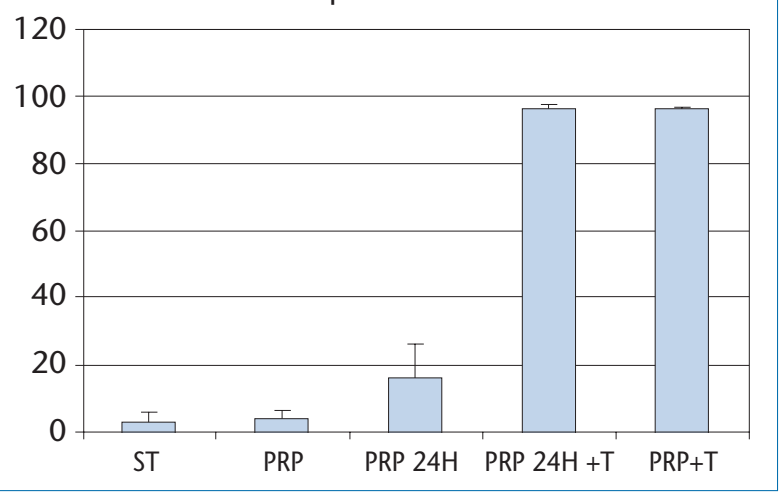

Figura 5. Representación gráfica de la media y desviación están-
dar del porcentaje de plaquetas CD62 positivas. Se determinó el porcentaje de expresión de CD62 en las muestras de 8 donantes sanos: (ST) sangre total, PRP fresco (PRP) y tras 24 horas de concon trombina (PRP+T y PRP $24 \mathrm{H}+\mathrm{T})$.

Figure 5. Graphical representation of the mean and standard deviatemperature (PRP 24H). In both PRP samples the analysis was also included after stimulation with thrombin (PRP+T and PRP $24 H+T)$. largely reversible, the changes that take place in the platelets during their processing and storage, act as useful parameters for predicting the clinical effectiveness of the concentrates. ${ }^{14}$

The analysis of the prepared PRP, according to the protocol for successive tube centrifugation, gives a result of concentrate enrichment that is between 3 and 4 times the recount of the platelets present in peripheral blood. This quantity of platelets is sufficient for achieving the local application objectives of this preparation, which is different from using platelets for transfusions. PRP obtained in this fashion allows the formation of a clot with an excellent consistency for transporting different types of bone grafts and biomaterials. This involves a supplementary supply to the middle of the lesion of a series of growth factors that act as mediators of the regenerative processes.

While some authors defend the idea that the biological activity of PRP derived from the supply of growth factors requires a quantity of between $0,9-1 \times 10^{6}$ platelets $/ \mu \mathrm{l}$ in the normal volume of concentrate $(6-10 \mathrm{ml}), 1$ there does not appear to be any conclusive study to demonstrate this. The number of platelets necessary for obtaining an adequate amount of each of the factors produced by the platelets has not been defined, in the same way that the number of cells contained in the concentrate is the only way of establishing the quantity of the factors released. Weibrich and Kleis compared two PRP preparation systems in their studies, through an analysis of platelet efficiency obtained with each system and the quantification of the principal growth factors contained in the final product. These authors conclude that, while there is a significant association between the number of platelets and the concentration of TGF- $\beta$, this association is not significant for the other factors analyzed (PDGF, IGF), and the number of platelets on their own cannot be used for predicting the quantity of growth factors that will be produced. The work by Zimmerman and cols. ${ }^{13}$ also had similar results in the analysis of the factors present in platelet concentrations obtained by different techniques. The authors stress the differences in the activation state of the platelets as one of the factors that contribute to this variability. DugrilIon and cols ${ }^{12}$ studied the platelet recount and the content 
En nuestro caso, el porcentaje de plaquetas activadas en el PRP fresco muestra cifras de entre $3-5 \%$ y del $16 \%$ a las 24 horas de almacenamiento. Estos datos se encuentran dentro del rango descrito en otras publicaciones que analizan concentrados de plaquetas de uso hematológico, en las que a las 24 horas el porcentaje de plaquetas activadas se encuentra entre el $7 \%,{ }^{19}$ y el $25 \% .{ }^{14}$ Desde el punto de vista funcional, se han observado buenos resultados con la utilización de concentrados en los que se describe la presencia de hasta un $20-30 \%$ de plaquetas activadas. ${ }^{20}$

Otro indicador de la viabilidad de las plaquetas en el PRP es la buena respuesta que se ha observado tras la estimulación con trombina, que se traduce en una correcta liberación del contenido de los depósitos intracelulares. La expresión de membrana de P selectina se acompaña en condiciones fisiológicas de la liberación y expresión de las otras moléculas contenidas en los reservorios, entre las que se encuentran los diferentes factores de crecimiento. ${ }^{21}$

Por último, en referencia al período de almacenamiento de los concentrados de plaquetas, es importante señalar que los hemoderivados procesados en circuito abierto no deben ser utilizados en un período posterior a 6 horas desde su preparación. EI PRP obtenido por doble centrifugación en tubo debe cumplir esta recomendación. De este modo, el hecho de que las plaquetas se encuentren en buen estado en el PRP analizado a las 24 horas parece dar un margen de garantía suficiente a la hora de afirmar el buen estado de las plaquetas y de su reserva funcional en el plazo de tiempo que contempla las condiciones habituales de aplicación.

\section{Conclusiones}

En el presente trabajo se demuestra que el protocolo de preparación del PRP descrito garantiza que los elementos celulares se mantienen de forma óptima hasta el momento de su utilización. El hecho de que las plaquetas sean activadas durante el acto quirúrgico y no antes, evita que los factores de crecimiento se pierdan en los procesos de preparación del concentrado o que se degraden de forma prematura.

\section{Bibliografía}

1. Marx RE. Platelet-rich plasma: evidence to support its use. J Oral Maxillofac Surg 2004;62:489-96.

2. Becerra J, Andrades JA, Santamaria JA, Cifuentes $M$, Guerado E. [Bone regeneration, cell therapy and tissue engineering]. Med Clin (Barc) 2001;116:23-34.

3. Sanchez AR, Sheridan PJ, Kupp LI. Is platelet-rich plasma the perfect enhancement factor? A current review. Int J Oral Maxillofac Implants 2003;18:93-103.

4. Marx RE, Carlson ER, Eichstaedt RM, Schimmele SR, Strauss JE, Georgeff KR. Platelet-rich plasma: Growth factor enhancement for bone grafts. Oral Surg Oral Med Oral Pathol Oral Radiol Endod 1998;85:638-46.

5. Anitua E. Plasma rich in growth factors: preliminary results of use in the preparation of future sites for implants. Int J Oral Maxillofac Implants 1999;14:529-35.

6. Schliephake $\mathrm{H}$. Bone growth factors in maxillofacial skeletal reconstruction. Int J Oral Maxillofac Surg 2002;31:469-84. in TGF- $\beta 1$ of the PRP subjected to different centrifugation strengths. This work clearly showed that intensities of over $800 \mathrm{~g}$ produced greater platelet efficiency, but the quantity of TGF- $\beta$, contained in the final product is reduced. This descent in the quantity of factors is a consequence of platelet activation on being subjected to important mechanical forces, with the resulting release into the medium of the granule contents, which is prematurely lost on removing the surplus fraction of plasma. As a result, the effectiveness of PRP is not only related to the fact that it contains a particular platelet concentration, but it is also related to the importance of guaranteeing that the platelets remain in tact until they are used.

In our study, the degree of platelet integrity in PRP is analyzed by studying the activation state and functional reserve. The measurement of CD62 expression and the response to stimulation with thrombin are the parameters frequently used for analyzing platelet concentrations, not only in local application but also for transfusional usage. ${ }^{14,16-18}$ The figure of $2,7 \%$ of platelet activation in extracted blood through venous puncture is in accord with previously published figures. ${ }^{19}$ In our case, the percentage of activated platelets in fresh PRP was between $3-5 \%$ and $16 \%$ atter being stored for 24 hours. These figures are within the range described in other publications that analyze the concentration of platelets for hematological use, in which the percentage of activated platelets is between $7 \%{ }^{19}$ and $25 \%$ after 24 hours. ${ }^{14}$ From a functional point of view, good results have been observed with concentrates containing a reported $20-30 \%$ of activated platelets. ${ }^{20}$

Another indicator of platelet viability in PRP is the positive response observed after thrombin stimulation, which results in a correct content release of intracellular deposits. The expression of membrane P-selectin is accompanied in physiological conditions by the release and expression of other molecules contained in the reservoirs, among which the different growth factors are found. ${ }^{21}$

Lastly, with regard to the storage period of platelet concentrates, it should be pointed out that blood derivatives, processed in an open circuit, should not be used after 6 hours of their preparation. The PRP obtained through double tube centrifugation should meet this recommendation. Thus, since platelets, analyzed in PRP after 24 hours, have been found in good condition, it would appear that this guarantees a sufficient margin as to their good condition and their functional reserve, which are required in usual conditions of the application period.

\section{Conclusions}

In this work the protocol described for preparing PRP, guarantees that the cell elements are maintained in the best condition until used. The fact that the platelets are activated during the surgical act and not before, avoids the loss of growth factors in the preparation processes of the concentrate, or their premature degradation. 
7. Weibrich G, Hansen T, Kleis W, Buch R, Hitzler WE. Effect of platelet concentration in platelet-rich plasma on peri-implant bone regeneration. Bone 2004;34:665-71.

8. Soffer E, Ouhayoun JP, Anagnostou F. Fibrin sealants and platelet preparations in bone and periodontal healing. Oral Surg Oral Med Oral Pathol Oral Radiol Endod 2003;95:521-8.

9. Sonnleitner D HPSD. A simplified technique for producing plateletrich plasma and platelet concentrate for intraoral bone grafting techniques: a technical note. Int J Oral Maxillofac Implants 2000;15:87982.

10. Kassolis JD, Rosen PS, Reynolds MA. Alveolar ridge and sinus augmentation utilizing platelet-rich plasma in combination with freezedried bone allograft: case series. J Periodontol 2000;71:1654-61.

11. Rodriguez A, Anastassov GE, Lee H, Buchbinder D, Wettan H. Maxillary sinus augmentation with deproteinated bovine bone and platelet rich plasma with simultaneous insertion of endosseous implants. J Oral Maxillofac Surg 2003;61:157-63.

12. Dugrillon A, Eichler H, Kern S, Kluter H. Autologous concentrated platelet-rich plasma (CPRP) for local application in bone regeneration. Int J Oral Maxillofac Surg 2002;31:615-9.

13. Zimmermann R, Jackubietz R, Jackubietz $M$, y cols. Different preparation methods to obtain platelet components as a source of growth factors for local application. Transfusion 2001;41:11217-24.
14. Wang C, Mody M, Herst R, Sher G, Freedman J. Flow cytometric analysis of platelet function in stored platelet concentrates. Transfus Sci 1999;20:129-39.

15. Weibrich G, Kleis WK. Curasan PRP kit vs. PCCS PRP system. Collection efficiency and platelet counts of two different methods for the preparation of platelet-rich plasma. Clin Oral Implants Res 2002;13:43743.

16. Schmitz G, Rothe G, Ruf A, y cols. European Working Group on Clinical Cell Analysis: Consensus protocol for the flow cytometric characterisation of platelet function. Thromb Haemost 1998;79:885-96.

17. Michelson AD. Flow cytometry: a clinical test of platelet function. Blood 1996; 87:4925-36.

18. Eppley BL, Woodell JE, Higgins BS. Platelet quantification and growth factor analysis from platelet-rich plasma: implications for wound healing. Plast Reconstr Surg 2004;114:1502-8.

19. Wyant TL, Smith PC, Brown B, Kantor AB. Whole blood microvolume laser scanning cytometry for monitoring resting and activated platelets. Platelets 2001;12:309-18.

20. Holme S, Sweeney JD, Elfath MD. The expression of p-selectin during collection, processing, and storage of platelet concentrates: relationship to loss of in vivo viability. Transfusion 1997;37:12-7.

21. Rendu F, Brohard-Bohn B. The platelet release reaction: granules' constituents, secretion and functions. Platelets 2001;12:261-73. 